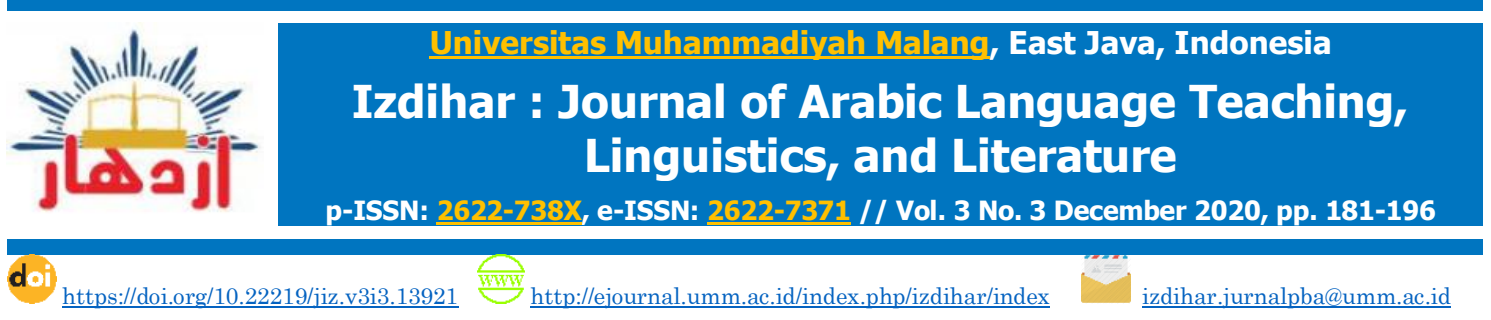

\title{
Akuarintar as a Media in Arabic Teaching and Learning for Deaf Towards Sustainable Development Goals (SDGS) 2030
}

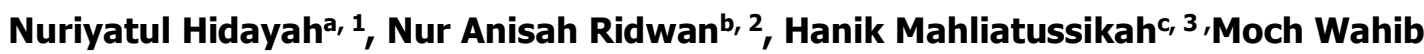

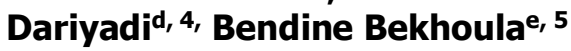 \\ $a, b, c, d$ Universitas Negeri Malang, Indonesia \\ Université Center Aflou, Algeria
1nuriyahidayah14@gmail.com*, 2nur.anisah.fs@um.ac.id, 3hanik.mahliatussikah.fs@um.ac.id, 4wahib.fs@um.ac.id, 5trezel@live.fr

\section{ARTICLE INFO}

\section{Article History:}

Received: 02/10/2020

Revised: 07/12/2020

Accepted: $31 / 12 / 2020$

Published: 31/12/2020

\section{*Corresponding}

\section{Author:}

Name: Nuriyatul Hidayah Email:

nuriyahidayah14@gmail.com

\section{Keyword}

\section{ABSTRACT}

Indonesia is a country that is familiar and closely related to Arabic. Therefore, learning this language becomes an important thing. This research was aimed to explain the development process and the validity level of Application of Arabic-Indonesian Expression Dictionary for Deaf (Akuarintar) as a media in Arabic teaching and learning for students at SMALB YPTB Malang. This research and development method used the ADDIE model which included Assessment/Analysis, Design, Development, Implementation, and Evaluation. The results of the validity test were the language validation test showed the proportion of $83 \%$. The results of material validation were $89 \%$, while the results of media design validation were $87 \%$, and the results of teacher validation were $87 \%$. The results of the Wilcoxon Rank Tests analysis obtained a significance value of $p=0.001$ and $z=-3.453$, which means that the students score of Arabic learning significantly increased after using the Akuarintar application. So, it can be concluded that Akuarintar is very suitable as a media for teaching and learning Arabic for the deaf.

Copyright (c) 2020, Hidayah et al This is an open access article under the CC-BY-SA license

Akuarintar; Arabic; Deaf; Dictionary

\section{مسرتخلص البدحث}

إندونيسيا دولة مألوفة وترتبط ارتباطًا وثيقًا باللغة العبية. لذلك يصبح تعلم هذه اللغة شيئًا مهمًا. يهدف هذا البحث إلى وصفف عملية التطوير

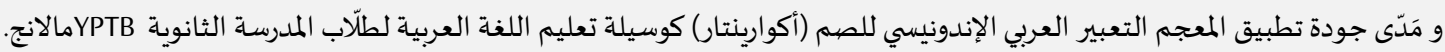

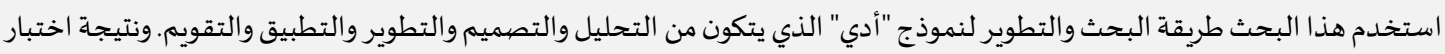

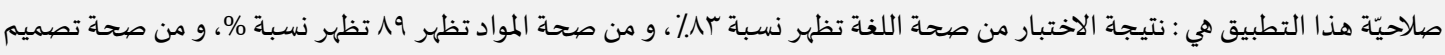

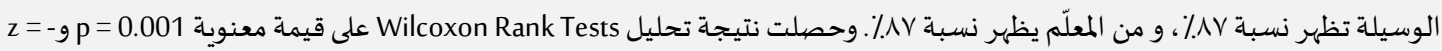

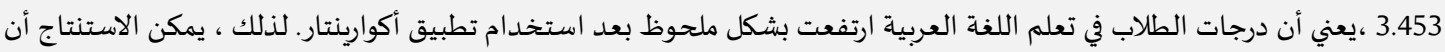
أكوارينتار مناسبة جدًا ليكون وسيلة لتعليم وتعلم اللغة العربية للصيم.

$$
\text { أكوارينتار؛ العربية؛ الصهم؛ المعجم }
$$

$$
\text { كلمات أسـاسية }
$$

Please cite this article as Hidayah, N., Ridwan, N.A., Mahliatussikah, H., Dariyadi, M.A., Bekhoula, B. (2020). Akuarintar as a Media in Arabic Teaching and Learning for Deaf Towards Sustainable 


\section{INTRODUCTION}

Arabic in the era of globalization is one of the languages that can exist and even tends to have significant development in non-Arabic countries (Ridho, 2015). Many languages are widely used in the world, in spoken, written, science, and technology, Arabic still exists in the world wide (Muis, 2020). According to experts, Arabic is considered to be one of the oldest Semitic language families and still exists in present time (Isnaini, 2018). The ability of Arabic has survived until now, partly due to its position as God's preferred language for His holy book (Alquran) (Wahab, 2014; Handriawan, 2015).

According to Al-Huri (2015) Arabic is one of the United Nations' six authorized languages, together with Chinese, Russian, English, French, and Spanish since 1974. Although not as prevalent as English, Arabic is the world's fifth most widely spoken language with 422 million speakers and has undergone significant developments not only in the Arab region but also in non-Arab countries (Jaafar, 2018). Arabic has become a scientific and academic language, as well as a popular language in the international community. Thus, using Arabic to convey scientific truths is important (Bulkisah, 2012).

Arabic also become a language that can accommodate the needs of its users and absorb various developments in science and technology in various fields (Syubar, 2000; Syamaun, 2016). This is caused by the elastic characteristics of Arabic, following to the qiyâs system, and is rich with isytiqâq and vocabularies. The ability of Arabic to adapt to the times, either through the creation of new vocabulary or terms or by borrowing foreign languages, is also considered extraordinary (Qaddur, 1999).

Indonesia is a country that is familiar and closely related to Arabic language. Arabic occupies a significant position because of its close relationship with daily religious beliefs and practices. Religious faith and practice are the main factors for Arabic teaching and learning for the first time in Indonesia in addition to several another factor such as trade (economy), social, culture, and politics (Tamam, 2014). This is also because Indonesia is a country with the largest Muslim population in the world (Albantani \& Madkur, 2019). Nasir (in Aziz \& Dinata, 2019) stated that Arabic is no longer a third foreign language but has become an important language and absolutely needs to be studied. Arabic is a second language for non-Arabic students in Indonesia (Pimada, Toba and Rasyidi, 2020). Jusoh and Abdullah (2020) said Indonesian people in daily activities often use Arabic to worship and socialize with Muslims, even though Arabic remains a foreign language for non-Arabic communities.

However, the reality is that not all children and citizens can get guidance, teaching, and learning Arabic easily, especially for people with disabilities, one of which is deaf. The deaf cannot perform all four language skills. According to Halah and Kauffman (in Zulmiyetri, 2017) deaf is a general term that indicates hearing difficulties which include all hearing difficulties from mild to severe, 
classified as deaf and hearing impaired. It affects their speaking ability because of the limited vocabulary that the brain absorbs. In fact, according to Uden and Meadow (in Adriana, 2017) deafness is not only results in the development of speech skills, but also the biggest impact that limited language skills. A deaf person only understands what he sees (visual language) so he can only see the writing in front of him, then he pays attention and mimics the way he reads, which is demonstrated by the teacher using sign language and lip language (Adhimah, Nurhidayati and Kholidah, 2018). According to Somantri, deafness can be interpreted as a state of hearing loss which results in a person unable to perceive various stimuli, especially through their sense of hearing (Juherna et al., 2020; Julita, 2015). Deaf children will find it difficult to know new things that have never been seen before (Nuraeni and Mardiah, 2020). In deaf children there is no sound imitation process, the imitation process is only limited to visual imitation (Adhimah, Nurhidayati \& Kholidah, 2018).

Apart from the limitations that are owned, the difficulty in obtaining knowledge and information is based on the lack of learning media that provide communication languages for the deaf (text or sign language). Inhibition of language skills experienced by deaf children has implications for their special needs to develop language skills with special methods and media (Hasibuan, Ritonga \& Novri, 2020). Children with special needs, including deaf, have different ways of Learning (Rachmayanti \& Alatas, 2020). There are already several media that can help the deaf in learning to improve their Arabic learning skills accompanied by the teacher in person. However, it is still rare that Arabic teaching and learning media for the deaf can be used by the deaf in learning Arabic independently.

As for development research that has been carried out before, including the Development of Sign Language Applications for the Recognition of Hijaiyah Letters for People with Disabilities of the Deaf (Huda, 2019), the Implementation of the Maternal Reflective Method in Arabic teaching and learning for Deaf Children at Special Needs School or Sekolah Luar Biasa (SLB) Purwosari Kudus (Rois \& Astina, 2018), Media Development of the Hijaiyah Letter Calendar for Learning to Read Arabic Letters for Deaf Students (Adhimah, Nurhidayati, \& and Kholidah, 2018), Augmented Reality Application of Hijaiyah Letters in Arabic Sign Language and Indonesian Sign Language or Sistem Bahasa Isyarat Indonesia (SIBI) (Utami \& Salamah, 2019), and etc. Some of these researches and developments make it easier for deaf students to know and learn Arabic. However, no research or development focuses on introducing Arabic to the level of words and simple expressions for deaf people. Therefore, to realize the right to obtain and education distribution by the vision for Sustainable Development (Sustainable Development Goals) 2016-2030 which has been agreed upon by all members of the United Nations at a meeting at the United Nation Headquarter, New York on 25-27 September 2015 (Ishartono \& Raharjo, 2015), it is necessary

Please cite this article as Hidayah, N., Ridwan, N.A., Mahliatussikah, H., Dariyadi, M.A., Bekhoula, B. (2020). Akuarintar as a Media in Arabic Teaching and Learning for Deaf Towards Sustainable 
to innovate learning facilities for the deaf in the form of media, methods and so on.

Based on these causes events, an application program called the ArabicIndonesian dictionary for the deaf (Akuarintar) was initiated, which is an alternative to simplify the Arabic learning process for deaf people in Indonesia. Apart from providing some original Arabic vocabulary and expressions in text form, this application program is also equipped with Sign language videos to make it easier for deaf children to understand Arabic pronunciation.

The focus of this research is explaining the development process of the Arabic-Indonesian Dictionary Application for the Deaf (Akuarintar) as an Arabic Learning Media at SMALB YPTB Malang, and explaining the level of validity of the Arabic-Indonesian Dictionary Application for the Deaf (Akuarintar) as Arabic Language Learning Media at SMALB YPTB Malang.

\section{METHOD}

The development of this learning media was based on Multimedia Instructional Design using the ADDIE model which includes Assessment/ Analysis, Design, Development, Implementation, and Evaluation. This model was chosen to help in creating educational programs that are effective and have a more systematic process. The ADDIE model was developed by Dick and Carey (1996) with 5 steps of research required in teaching and learning activities. The five components are: (1) Analysis; (2) Design; (3) Development; (4) Implementation; (5) Evaluation.

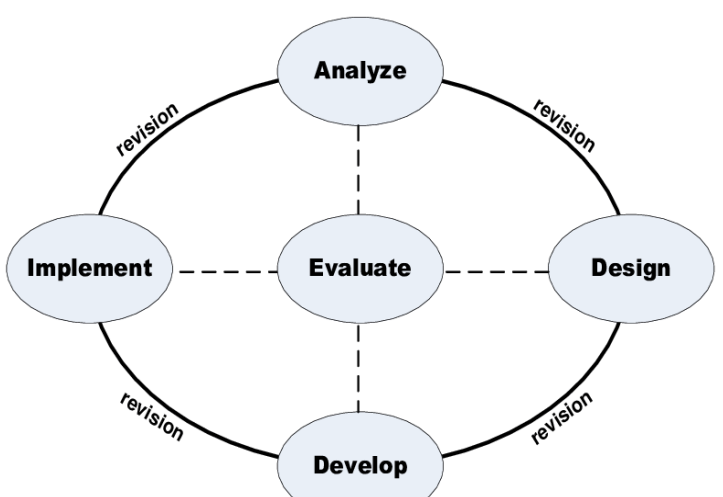

Figure 1. The ADDIE Development Model (Anggraeni, Elmunsyah and Handayani, 2019)

ADDIE steps from Figure 1 can be seen that what needs to be done in this ADDIE approach is to analyze student characteristics and material needs then design an application appearance that suits material needs, developing media, introducing the application to students, and conduct evaluations to measure the level of validation and effectiveness of the application in increasing student 
success in learning. So that the combination of the five components becomes a good unity to increase student motivation and achievement.

The subjects of this study were students of Yayasan Pendidikan Tunas Bangsa Special Needs Senior High School or Sekolah Menengah Atas Luar Biasa Yayasan Tunas Bangsa (SMALB YPTB) Malang which was located on Brigjen Slamet Riadi street number 126 Malang, Oro Oro Dowo, Klojen district, Malang City. These high school students are deaf students with special needs. The number of students who became research subjects was 18 students.

In this Akuarintar application development, five methods were used in data collection, those are: (1) interviews, this method was used in research to collect data in the form of analysis of the initial situation and the problems underlying the research, (2) a literature study was used to find knowledge related to learning media and deafness on the internet and in printed books. (3) questionnaires are used at the application step to measure the feasibility of products that have been made both at the review step of linguists, experts, media experts, teachers, and students during field trials (4) tests, used at the implementation or application step which will be done by means of pre-test and post-test in the form of multiple-choice questions to measure student knowledge before and after using the Akuarintar application (5) recording documents or documentation, this is used in research to collect data and describe the product development report of the Akuarintar application according to with the development model used. On the other hand, the instruments used to collect data in this research and development were interview instruments, questionnaire sheets, objective test sheets, and product development reports.

There are two data obtained from this research and development, those are: (1) qualitative data for product design and validation, (2) quantitative data for product validation, and product effectiveness. Qualitative and quantitative data were obtained from the results of reviews from linguists, material experts, media experts, teachers, and students from the process of needs analysis to field trials.

In this development research, three data analysis techniques were used, namely: (1) qualitative descriptive analysis, which was used to process data from the review results of linguists, material experts, media experts, teachers, and students. This data analysis technique was carried out by grouping information from qualitative data. In the form of input, responses, criticism, and suggestions for improvements contained in the questionnaire and interview results. The results of this analysis are then used to revise the product being developed; (2) quantitative descriptive analysis, this is used to process the data obtained through a questionnaire in the form of a percentage. The formula used to calculate the percentage of each subject according to Tegeh and Kirna (2010) is in Table 1.

Please cite this article as Hidayah, N., Ridwan, N.A., Mahliatussikah, H., Dariyadi, M.A., Bekhoula, B. (2020). Akuarintar as a Media in Arabic Teaching and Learning for Deaf Towards Sustainable 
Table 1. Percentage Range and Product Validity Criteria (Akbar, 2016)

\begin{tabular}{|c|c|}
\hline Percent range (\%) & Qualitative Criteria \\
\hline $85,01 \%-100 \%$ & Very Valid \\
\hline $70,01 \%-85 \%$ & Quite Valid \\
\hline $50,01 \%-70 \%$ & Less Valid \\
\hline $01,00 \%-50 \%$ & Invalid \\
\hline
\end{tabular}

Table 1 explained percentage range and product validity criteria. The data analysis technique used to determine the difference or significance of the pretest and posttest scores was to use the paired sample t-test (if the data were normally distributed) and the Wilcoxon rank tests (if the data were not normally distributed). In addition, it also uses Normalized Gain (N-gain) calculations to determine the increase in the value of each student.

\section{RESULTS \& DISCUSSION}

\section{The Development Process of the Arabic-Indonesian Dictionary Application for the Deaf (Akuarintar)}

Children with special needs, including deaf, have different ways of Learning. There are already several media that can help the deaf in learning to improve their Arabic learning skills accompanied by the teacher in person. However, it is still rare that Arabic teaching and learning media for the deaf can be used by the deaf in learning Arabic independently. In addition, no research or development in Indonesia has yet focused on introducing Arabic at the level of words and simple expressions for deaf people. Mostly the previous researches still focus on the level of learning hijaiyah letters or how to read the Holy Qur'an. Based on these causes events, an application program called the ArabicIndonesian dictionary for the deaf (Akuarintar) was initiated, which is an alternative to simplify the Arabic learning process for deaf people in Indonesia.

The Akuarintar Application Development using the ADDIE Model. The first step in the ADDIE development model is analysis. The first analysis was carried out on 15 students and 1 teacher at SMALB YPTB Malang in the form of an analysis of student characteristics. Researchers conducted interviews with 4 students and 2 teachers. In addition, the researcher gave a questionnaire to 15 students to collect data. From this analysis, it can be concluded that deaf students are enthusiastic about learning Arabic because the majority of them are Muslim. On the other hand, these deaf students are students who are enthusiastic about new things. Even though learning a foreign language is quite a challenge for them. They still want to try to learn that.

The second analysis was the analysis of student needs. Deaf students need a media that is able to help improve the memorization of simple Arabic vocabulary and expressions equipped with Arabic writing and original Arabic Sign 
language videos. Sign language videos in each vocabulary and simple expressions are made so that students are able to imitate sign language and students are able to recognize and imitate the original Arabic Sign language. Both analyzes were carried out on 30 April 2020-02 May 2020. the technique used to determine the difference or significance of the pretest and posttest scores was to use the paired sample t-test (if the data were normally distributed) and the Wilcoxon rank tests (if the data were not normally distributed). In addition, it also uses Normalized Gain (N-gain) calculations to determine the increase in the value of each student.

The next step was design. At this step, an application is designed to be developed according to the results of the analysis previously carried out. Requirements design was done by analyzing the design of the application system to be built and designing a design draft or application wireframe. The need for features was done by collecting and producing data first to support the application. After collecting and analyzing the features, interface design was carried out using Adobe Photoshop which consisted of several pages. After that, the coding step was carried out to begin developing into an application through the programming coding step. This coding was done with the help of the Android Studio IDE in Kotlin and entering the previous collection data into the application database using the realm library. For the design, it is also necessary to do coding from the design to the XML form so that it appears on the Android Handphone. The design process starts from May 2, 2020, to May 28, 2020.

The third step was the development. The development step was the product realization step. At this step, the development of the AKUARINTAR application was carried out according to the design. After that, the application was validated by validators who were experts in these fields. This study consisted of four validation steps, namely (1) validation by linguists, (2) validation by material experts, (3) validation by media experts and (4) validation by teachers. Here are some examples of layouts of the application:

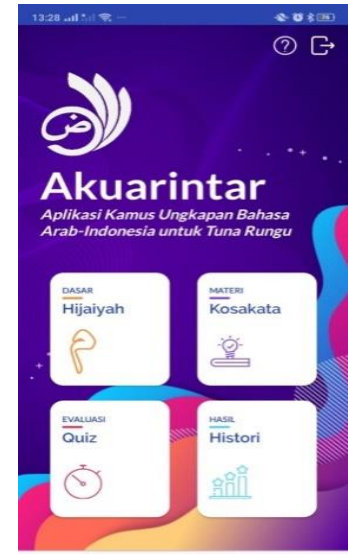

Figure 2. Main Page

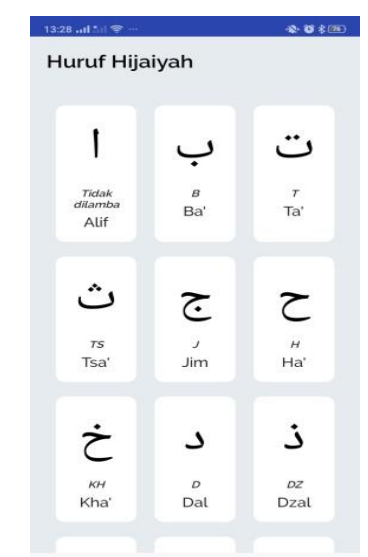

Figure 3. Hijaiyah Letter Feature

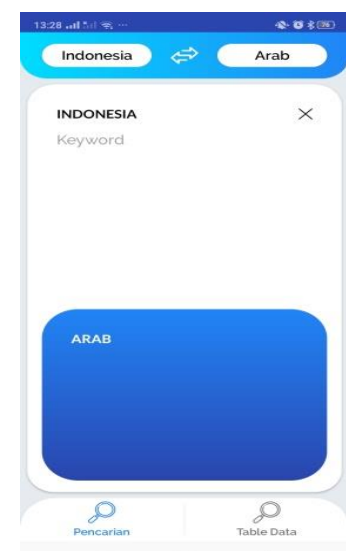

Figure 4. Search Feature

Please cite this article as Hidayah, N., Ridwan, N.A., Mahliatussikah, H., Dariyadi, M.A., Bekhoula, B. (2020). Akuarintar as a Media in Arabic Teaching and Learning for Deaf Towards Sustainable Development Goals (SDGS) 2030. Izdihar : Journal of Arabic Language Teaching, Linguistics, and Literature, 3(3), 181-196. DOI: https://doi.org/10.22219/jiz.v3i3.13921 


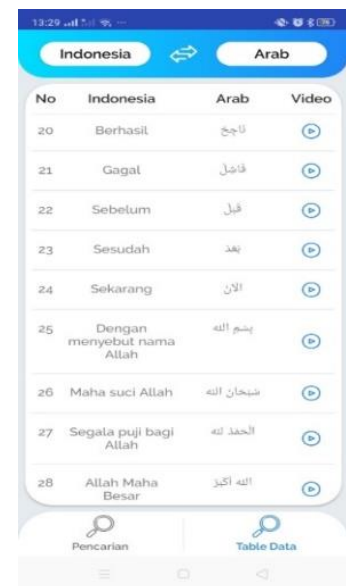

Figure 5. Vocabulary Table Feature

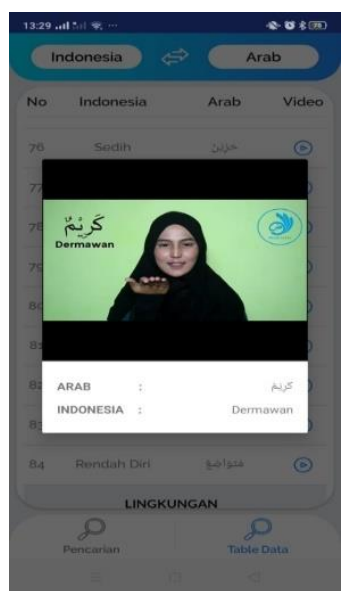

Figure 6. Sign Language Video Feature

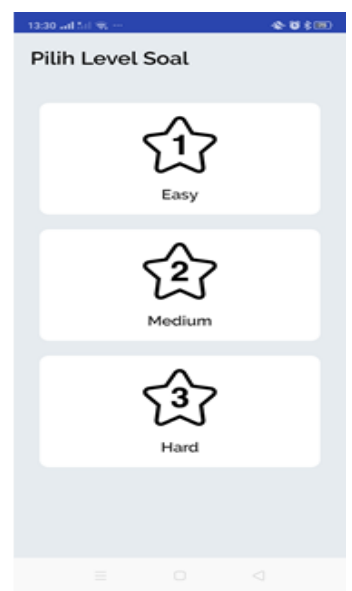

Figure 7. Quiz Feature

From the Figure 2 to Figure 7, it can be seen that this application has several features. The features were hijaiyah letter feature, search feature, vocabulary table feature, sign language video feature, and quiz feature.

The fourth step of the ADDIE development model was implementation. The implementation was limited to SMALB YPTB Malang. Student learning outcomes data obtained from the pretest and posttest scores respectively.

The fifth step was the evaluation. At this step, the researcher made the final revision of the Akuarintar application which was developed based on the input obtained from the response questionnaire or field notes on the observation sheet. It was intended so that the application developed is truly appropriate and can be used by a wider school.

\section{The Level of Validity of the Arabic-Indonesian Dictionary Application for the Deaf (Akuarintar)}

The data from the questionnaire results of the linguist on Akuarintar that have been validated by linguists get a cumulative score of 40 out of 12 questions with a percentage of $83 \%$. The cumulative score was obtained by calculating the 4 indicators of the language validity scale. Thus, the language in the developed of Akuarintar obtained very valid criteria. Meanwhile, the qualitative data from the language validator was that there were still some words that are not consistent from the harakat aspect and there are several sentences that need to be refined in the choice of words.

Akuarintar material was validated by material experts with a cumulative value of 43 out of 12 statements with a percentage of $89 \%$. Cumulative results were obtained through the calculation of 4 validity scale indicators. Thus, products developed in terms of content get very valid criteria. The validator suggested adding more and varied exercises so that students practice more often 
in Arabic applications, and the content display needs to be simplified to make it more practical.

The cumulative value of the questionnaire obtained from the media validator was 42 of the 12 questionnaire statements with a percentage of $87 \%$ obtained through the calculation of 4 validity scale indicators based on the number of statements. So, products developed in terms of media get very valid criteria. The media validator provides suggestions to improve the instructions for using the dictionary, adds a pop-up question for exiting the certainty of the application before the user actually exits the application, and clarifies the description of hijaiyah letters that are still truncated.

The cumulative score for the questionnaire obtained by the teacher in the Arabic language development program as a field test was 42 out of 12 statements with a percentage of $87 \%$ obtained by calculating 4 validity scale indicators based on the number of statements. So, the product developed was feasible to be applied in learning Arabic at the Special School. The validator provides suggestions for material enrichment on the theme of pronouns or isim dhamir. Then, before carrying out the field test or application in Arabic learning, the researcher made a revision of the development product based on the evaluation of the language, material, media, and teacher validators to improve the quality of the application.

The fourth step of the ADDIE development model was implementation. The implementation was limited to SMALB YPTB Malang. Student learning outcomes data obtained from the pretest and posttest scores respectively. The data obtained from the pretest and posttest were analyzed quantitatively using descriptive statistical methods, comparison of the N-gain value, and the Wilcoxon Rank Test. Descriptive statistics are presented in Table 1 which includes the value of $\mathrm{N}$, minimum, maximum, average, and standard deviation (SD). The $\mathrm{N}$-gain value was used to see how much increase in the pretest and posttest scores of each student.

Table 2. Descriptive Statistics of Pretest, Posttest and N-gain Values

\begin{tabular}{llll}
\hline Statistics & Pretest & Posttest & $\mathbf{N}$-gain \\
\hline Number of data (N) & 16 & 16 & 16 \\
\hline Minimum Score & 45 & 55 & 0.00 \\
\hline Maksimum & 65 & 80 & 0.43 \\
\hline Average & 55.94 & 64.69 & 0.198 \\
\hline Standard Deviation (SD) & 5.836 & 6.183 & 0.109 \\
\hline Skewness & 0.163 & 1.100 & 0.374 \\
\hline
\end{tabular}

In the Table 2, it can be seen that the skewness score at the pretest was 0.163 and the posttest was 1,100 . Based on these results, the posttest skewness

Please cite this article as Hidayah, N., Ridwan, N.A., Mahliatussikah, H., Dariyadi, M.A., Bekhoula, B. (2020). Akuarintar as a Media in Arabic Teaching and Learning for Deaf Towards Sustainable Development Goals (SDGS) 2030. Izdihar : Journal of Arabic Language Teaching, Linguistics, and Literature, 3(3), 181-196. DOI: https://doi.org/10.22219/jiz.v3i3.13921 
value was not in the interval $[-1,1]$ so that the data were not normally distributed. So, the difference test is carried out using the Wilcoxon Rank Test to determine the difference in the average pretest and posttest scores, whether they differ significantly or not. From the results of the Wilcoxon Rank Tests analysis, it was found that the significance value was $p=0.001$ and $z=-3.453$. This value is $p$ less than 0.005 , so it can be concluded that there is a significant difference between the pretest and posttest scores. That is, the value of students' Arabic learning outcomes significantly increased after using the Akuarintar application.

Arabic is a language that is unique enough for the deaf to learn. Based on research conducted by researchers, English is studied more than Arabic. However, that doesn't mean that the deaf are not interested in learning Arabic. Because in the psychological aspect, the deaf always want to know new things (Larasati, 2017). In addition, for deaf people who are Muslims, learning Arabic is very important (Turohmah, Mayori, \& Sari, 2019). Because the holy book of Muslims in Arabic (Nur \& Rini, 2017).

The knowledge of children with hearing disabilities in this study is still low. We can understand this because of limited information and understanding of Arabic for deaf children. Almost all deaf children who are the subject of this study have low literacy due to difficulties in understanding vocabulary. This is partly due to Arabic learning media for Deaf is still very rare. Even though the role of learning media is very important in motivating children to read and learn new knowledge (Nuraini \& Carwadi, 2017). Therefore, it is necessary to have Arabic language learning media and education on a regular basis for children, especially children with hearing impairment.

Deafness, as well as other disabilities who are Indonesian citizens have the right to obtain proper education. As stated by Effendy et al (in Anugerah, Ulfa, \& Husnah, 2020), it is known that children with special needs need more attention to increase their focus on the learning process, besides that the role of sign language is very important. Notoatmodjo (in Nuraini \& Carwadi, 2017) states that according to several theories, knowledge is obtained more through the sense of sight (eyes) besides that knowledge can also be obtained and enhanced through direct experience or through the experiences of others. Deaf children learn everything through visuals (Fibrianti \& Wijiastuti, 2020). The impact of hearing loss for individuals is to have a small vocabulary, so it needs to be maximized in their sense of sight in learning (Anugerah, Ulfa, \& Husnah, 2020). Therefore, an attractive visual media is needed to support the learning process of deaf children. One of the visual media that can attract deaf children is visual media based on android. Currently, androids are very familiar among all students, even students who are deaf. Android is offered to help one's daily activities, one of which is learning activities (Sun'iyah, 2020). Android is a Linux operating system that supports the running of hardware such as cellphones, smartphones and PC tablet (Nazruddin, 2012). Therefore, visual media based on android and containing sign language are important. 
The concept development process will be easy to build when it occurs besides the interaction of students with the teacher, but can also be obtained through interaction and communication with learning resources (Khomsah \& Imron, 2020). One way is to use quizzes. Learning is more effective and fun with the quiz feature (Hikmah, Apriyani, \& Purwandhani, 2020). This is in accordance with student responses to quizzes in the Akuarintar application. They enjoy the quiz in the application as a medium for their independent evaluation.

The challenge of the needs of students with special needs requires empathy and high awareness from educators and parents. Teachers are required to have more competence in developing media and learning resources that are adaptive to the needs of their students. To do this, educators need to have adequate media literacy and ICT skills (Alfindasari \& Surahman, 2014). Therefore, the presence of Akuarintar with several features such as tables of Arabic vocabulary and expressions, Sign language videos, and quizzes is expected to be one of the media that can facilitate the learning process of Arabic for the deaf.

\section{CONCLUSIONS}

The results of this application development research indicate that the Akuarintar application is very feasible to be applied as a media for teachinglearning Arabic for deaf people. This is based on the results of the linguist validation test with a cumulative score of 40 with a percentage of $83 \%$ which means very valid, validation of material experts with a score of 43 with a percentage of $89 \%$ which means very valid, validation of media experts with a score of 42 with a percentage of $87 \%$ which means very valid and validation from the teacher with a score of 42 with a percentage of $87 \%$ which means very valid. From the results of the Wilcoxon Rank Tests analysis, it was found that the significance value was $p=0.001$ and $z=-3.453$. This value is $p$ less than 0.005 , so it can be concluded that there is a significant difference between the pretest and posttest scores. That is, the value of students' Arabic learning outcomes increased significantly after using the Akuarintar application. Finally, researchers suggest other researchers continue this research with better quality and in a wider scope especially by increasing the vocabulary, themes and sign language videos in this dictionary, increasing the types of quizzes in this dictionary, improving the layout of the application and implementing this application in other extraordinary schools so that other advantages and disadvantages of this application can be seen. In addition, through this research the researcher hopes to inspire further researchers to develop other learning media to support learning Arabic for the deaf.

Please cite this article as Hidayah, N., Ridwan, N.A., Mahliatussikah, H., Dariyadi, M.A., Bekhoula, B. (2020). Akuarintar as a Media in Arabic Teaching and Learning for Deaf Towards Sustainable 


\section{ACKNOWLEDGMENT}

The researchers wish to express their gratitude to LP2M UM, Mr. Muhammad Choiru Nasta'in, Mr. Riski Kurniawan and all who have who have major roles in helping to prepare Akuarintar, both materially and immaterially.

\section{BIBILIOGRAPHY}

Adhimah, I., Nurhidayati and Kholidah, L. N. (2018). Pengembangan Media Kalender Huruf Hijaiyyah Untuk Pembelajaran Membaca Huruf Arab Bagi Siswa Tunarungu. in Prosiding Konferensi Nasional Bahasa Arab IV. Malang: Jurusan Sastra Arab Fakultas Sastra Universitas Negeri Malang, pp. 200-211.

Adriana, I. (2017). Kemampuan Artikulasi Bunyi Bahasa Arab Pada Anak Tunarungu (Studi Kasus di SLB Negeri Sampang) Iswah. Nuansa, 14(2), pp. 333-361. DOI:http://dx.doi.org/10.19105/nuansa.v14i2.1639.

Akbar, S. (2016) Instrumen Perangkat Pembelajaran. Bandung: PT. Remaja Rosdakarya.

Al-Huri, I. (2015). Arabic Language: Historic and Sociolinguistic Characteristics. English Literature and Language Review, 1(4), pp. 28-36. DOI: https://doi.org/10.13140/RG.2.2.16163.66089/1.

Albantani, A. M. and Madkur, A. (2019). Teaching Arabic in the era of Industrial Revolution 4.0 in Indonesia: Challenges and opportunities. ASEAN Journal of Community Engagement, 3(2). pp. 196-213. DOI: https://doi.org/10.7454/ajce.v3i2.1063.

Alfindasari, D. and Surahman, E. (2014). Sumber Daya Manusia dan Pendidikan di Era Global: Sebuah Tinjauan Terhadap Penelitian Teknologi Pendidikan di LPTK. Proceeding Seminar Nasional Teknologi Pembelajaran, pp. 1-15.

Anggraeni, D. R., Elmunsyah, H. and Handayani, A. N. (2019). Pengembangan modul pembelajaran fuzzy pada mata kuliah Sistem Cerdas untuk mahasiswa S1 Pendidikan Teknik Elektro Universitas Negeri Malang. TEKNO Jurnal Teknologi, Elektro, dan Kejuruan, 29(1), pp. 26-40. Available at: http://journal2.um.ac.id/index.php/tekno.

Anugerah, S., Ulfa, S. and Husna, A. (2020). Pengembangan Video Pembelajaran Bahasa Isyarat Indonesia (Bisindo) Untuk Siswa Tunarungu Di Sekolah Dasar. JINOTEP (Jurnal Inovasi dan Teknologi Pembelajaran): Kajian dan Riset Dalam Teknologi Pembelajaran, Л2), pp. 76-85. DOI: https://doi.org/10.17977/um031v7i22020p076. 
Aziz, A. and Dinata, Y. M. (2019). Bahasa Arab Modern Dan Kontemporer; Kontinuitas Dan Perubahan. Jurnal Mumtäz: Jurnal Studi Al-Quran dan Keislaman, 3(1), pp. 152-168. DOI: https://doi.org/10.36671/mumtaz.v3i2.38.

Bulkisah, B. (2012). Pembelajaran Bahasa Arab Pada Perguruan Tinggi Agama Islam Di Indonesia. Jurnal Ilmiah Didaktika, 12(2), pp. 308-318. DOI: https://doi.org/10.22373/jid.v12i2.455.

Fibrianti, F. D. and Wijiastuti, A. (2020). Pengembangan Media Pola Kalimat Sederhana Berbasis Android Pada Pembelajaran Sains Universitas Negeri Surabaya. Jurnal Pendidikan Khusus, 15(1). https://ejournal.unesa.ac.id/index.php/jurnal-pendidikankhusus/article/view/34746

Handriawan, D. (2015). Mempertegas Kembali Arah Pembelajaran Bahasa Arab ( Perspektif Budaya Terhadap Tradisi Belajar Bahasa Arab di Indonesia. al Mahāra: Jurnal Pendidikan Bahasa Arab, 1(1), pp. 53-78. DOI: https://doi.org/10.14421/almahara.2015.011-03.

Hasibuan, I. W., Ritonga, S. and Novri (2020). Komunikasi Nonverbal Guru pada Murid Tunarungu dalam Meningkatkan Kemampuan Berinteraksi Sosial Teacher 's Nonverbal Communication for Tunarungu Students in Increasing the Ability Social. PERSPEKTIF, 9(1), pp. 19-26. DOI: http://dx.doi.org/10.31289/perspektif.v9i1.2584.

Hikmah, A. B., Apriyani, Y. and Purwandhani, S. A. (2020). Aplikasi Pembelajaran Huruf Hangeul Berbasis Android. Jurnal Informatika, 71$)$, pp. 24-29. DOI: https://doi.org/10.31311/ji.v7i1.6390.

Huda, N. (2019). Aplikasi Bahasa Isyarat Pengenalan Huruf Hijaiyah Bagi Penyandang Disabilitas Tuna Runggu', Jurnal Sisfokom (Sistem Informasi dan Komputer). $\quad 08(01), \quad$ pp. $1-6 . \quad$ DOI: https://doi.org/10.32736/sisfokom.v8i1.582.

Ishartono and Raharjo, S. T. (2015). Sustainable Development Goals ( Sdgs ) Dan Pengentasan Kemiskinan. Social Work Jurnal, 6(2), pp. 154-272. DOI: https://doi.org/10.24198/share.v6i2.13198.

Isnaini, R. L. (2018). Revitalisasi Peran Bahasa Arab Untuk Mengatasi Konflik Dalam Perspektif Multikultural. Jurnal Pembangunan Pendidikan: Fondasi dan Aplikasi Volume, 6(1), pp. 15-26. DOI: https://doi.org/10.21831/jppfa.v6i1.22554. 
Jaafar, E. A. (2018). Arabize, Arabization and Arabic Language. University of Baghdad: Baghdad. DOI: https://doi.org/10.13140/RG.2.2.20185.98409.

Juherna, E. et al. (2020). Implementasi Pendidikan Karakter Pada Disabilitas Anak Tunarungu. Jurnal Golden Age, Universitas Hamzanwadi, 4(1), pp. 12-19. http://e-journal.hamzanwadi.ac.id/index.php/jga/article/view/1809.

Julita, V. O. (2015). Efektivitas Metode Vakt Untuk Meningkatkan Hafalan Surah Al-Kautsar Bagi Anak Tunarungu. E-Jupekhu (Jurnal IImiah Pendidikan Khusus), 4(3), pp. 615-626. DOI: https://doi.org/10.24036/jupe72000.64.

Jusoh, Z. and Abdullah, L. (2020). ESL Student Teachers Beliefs about Learning Arabic as a Foreign Language. International Journal of Asian Social Science, 1011), pp. 43-50. doi: http://doi.org/10.18488/journal.1.2020.101.43.50.

Khomsah, A. F. and Imron, M. (2020). Pembelajaran Bahasa Arab melalui Kolaborasi Metode Questioning dan Media Kahoot. Tarbiyatuna: Jurnal Pendidikan Ilmiah, 5(1), pp. 99-118. http://ejournal.kopertais4.or.id/mataraman/index.php/tarbiyatuna/article/vi ew/3867

Larasati, I. D. (2017). Pola Komunikasi Interpersonal Anak Tunarungu di Sekolah Inklusi. Jurnal Pendidikan Khusus, 9(2) pp. 1-7. https://jurnalmahasiswa.unesa.ac.id/index.php/jurnal-pendidikankhusus/article/view/18904

Muis, M. (2020). Bahasa Arab Di Era Digital: Eksistensi Dan Implikasi Terhadap Penguatan Ekonomi Keumatan. Al-Fathin, 3(1), pp. 60-70. DOI: https://doi.org/10.32332/al-fathin.v3i01.2319.

Nur, I. R. and Rini, F. S. (2017). Penerapan Metode Langsung Dalam Pengajaran Bahasa Arab Di Pondok Pesantren Al-Islam Joresan Ponorogo. Khadimul Ummah: Journal of Social Dedication, 1(1), pp. 1-8. DOI: http://dx.doi.org/10.21111/ku.v1i1.1417.

Nuraeni, T. and Mardiah, L. N. (2020). Bagaimanakah Proses Belajar Anak Tunarungu dan Anak Autisme?: Studi Kasus di Salah Satu SLB di Indramayu. Gema Wiralodra, 11(1), pp. 133-142. DOI: https://doi.org/10.31943/gemawiralodra.v11i1.115

Nuraini, Daniah and Carwadi (2017). Efektivitas Media Aplikasi untuk Edukasi Siaga Bencana pada Anak Penyandang Disabilitas (Tuna Rungu). Jurnal Ilmiah Kesehatan, 16(1), pp. 4-13. DOI: http://journals.stikim.ac.id/index.php/jikes/article/view/406. 
Pimada, L. H., Toba, R. and Rasyidi, A. W. (2020). Learning of Imla' Using Flashcards on Writing Skill at Islamic Elementary School Level in Samarinda. Izdihar: Journal of Arabic Language Teaching, Linguistics, and Literature, 3(1), pp. 1-16. DOI: http://ejournal.umm.ac.id/index.php/izdihar/article/view/11682.

Qaddur, A. M. (1999). Madkhal ilâ Fiqh al-Lughah al-'Arabiyyah. Damaskus: Dar al-Fikr.

Rachmayanti, I. and Alatas, M. A. (2020). The Learning of Arabic Alphabets for Special Needs Students in Elementary School. Izdihar: Journal of Arabic Language Teaching, Linguistics, and Literature, 3(2), pp. 79-94. DOI: https://doi.org/10.22219/jiz.v3i2.11931.

Ridho, U. (2015). Bahasa Arab dalam pusaran arus globalisasi: Antara pesismisme dan optimisme. Ihya Al-Arabiyah: Jurnal Pendidikan Bahasa Dan Sastra Arab, 1(2), pp. 226-210. https://www.neliti.com/id/publications/265488/bahasa-arab-dalampusaran-arus-globalisasi-antara-pesismisme-dan-optimisme.

Rois, A. and Astina, C. (2018). Implementasi Metode Maternal Reflektif Dalam Pembelajaran Bahasa Arab Bagi Anak Tuna Rungu Di Slb Purwosari Kudus. Jurnal PPKM III, $\quad$ pp. $372-387 . \quad$ DOI: https://doi.org/10.32699/ppkm.v5i3.486.

Safaat and Nazruddin (2012). Pemrograman Aplikasi Mobile Smartphone dan Tablet PC Berbasis Android. Bandung: Informatika.

Sun'iyah, S. L. (2020). Media Pembelajaran Daring Berorientasi Evaluasi Pembelajaran pada Materi Pelajaran PAI di Tingkat Pendidikan Dasar. Dar ElIlmi: Jurnal Studi Keagamaan, Pendidikan, dan Humaniora,. 71 1). pp. 1-18. http://www.e-jurnal.unisda.ac.id/index.php/dar/article/view/2024

Syamaun, N. (2016). Pembelajaran Maharah al-Kalam untuk Meningkatan Keterampilan Berbicara Mahasiswa Program Studi Pendidikan Bahasa Arab Fakultas Tarbiyah dan Keguruan UIN Ar-Raniry Banda Aceh. Jurnal IImu Bahasa Arab dan Pembelajarannya, 4(2), pp. 343-359. DOI: http://dx.doi.org/10.22373/l.v4i2.852.

Syubar, S. (2000) Al-Mushthalah Khiyâr Lughawî wa Simah Hadhâriyyah. Qatar: kitab al-Ummah.

Tamam, A. M. (2014). Program Penyiapan Dan Pembinaan Guru Bahasa Arab Profesional Di Indonesia. Arabiyat: Jurnal Pendidikan Bahasa Arab dan 
Kebahasaaraban, 1(1), pp. 49-62. DOI: http://dx.doi.org/10.15408/a.v1i1.1130.

Tegeh, I. M. and Kirna, I. M. (2010). Pengembangan Bahan Ajar Metode Penelitian Pendidikan Dengan Addie Model. E-Jurnal Undiksa, 11(1), pp. 1226. DOI: http://dx.doi.org/10.23887/ika.v11i1.1145.

Turohmah, F., Mayori E., Sari, R. Y. (2019). Media pembelajaran Word Wall dalam meningkatkan kemampuan mengingat kosa kata bahasa Arab. Jurnal Pendidikan Luar Sekolah, 13(2), pp. 13-19. DOI: http://dx.doi.org/10.32832/jpls.v14i1.3176.

Utami, F. N. and Salamah, U. (2019). Aplikasi Augmented Reality Pembelajaran Huruf Hijaiyah dalam Bahasa. JURNAL RESTI (Rekayasa Sistem dan Teknologi Informasi), 3(1), pp. 1-10. DOI: https://doi.org/10.29207/resti.v3i1.693.

Wahab, M. A. (2014). Peran Bahasa Arab Dalam Pengembangan Ilmu Dan Peradaban Islam. Arabiyat: Jurnal Pendidikan Bahasa Arab dan Kebahasaaraban, 1(1), pp. 1-20. DOI: https://doi.org/10.15408/a.v1i1.1127.

Zulmiyetri (2017). Metoda Maternal Reflektif (MMR) untuk Meningkatkan Kemampuan Bahasa Lisan Anak Tunarungu. Jurnal Konseling dan Pendidikan, 5(2), pp. 62-67. DOI: https://doi.org/10.29210/117500. 